УДК 94(517):004.9

ББК 63.3(5Мон)

\title{
ОПЫТ ПРИМЕНЕНИЯ ГИС В ИССЛЕДОВАНИЯХ СОВРЕМЕННОГО КОЧЕВНИЧЕСТВА МОНГОЛИИ
}

В статье рассмотрены возможности применения ГИС-технологий в изучении современного состояния кочевничества Монголии. Показаны основные средства пространственного анализа на примере использования известной геоинформационной программы ArcGIS.

Ключевые слова: ГИС, Монголия, кочевки, домохозяйства.

A.D. GOMBOZHAPOV

\section{THE USE OF GEOGRAPHIC INFORMATION SYSTEMS IN THE STUDY OF MODERN NOMADISM OF MONGOLIA}

The Paper is devoted to the possibility of using GIS technologies in the study of the current state of Mongolian nomadism. The main tools of spatial analysis are shown by the example of using the well-known geographic information program ArcGIS.

Keywords: GIS, Mongolia, migrations, households.

Одной из особенностей исследований кочевого образа жизни является необходимость выявления пространственных характеристик. Потребности постоянных перемещений скотоводов, носящие по большей части сезонный характер, вызваны необходимостью регулярной смены пастбищ, зависимостью от водного режима той или иной области и другими экологическими факторами. И все же напрямую связывать степень мобильности животноводов только от биологических потребностей домашнего скота было бы некорректно. Ряд социальных и экономических условий играют не меньшую роль в организации кочевок. Особенно заметно их влияние возросло в последние годы, в частности сказалось на протяженности и характере кочевок, а также на длительности пребывания на сезонных стоянках и их количестве. Поскольку мобильность и межсезонные миграции кочевых скотоводов есть выражение взаимовлияния многих фракторов, то интегрирующим показателем изменений, происходящих в кочевничестве, становится степень подвижности или, наоборот, оседлости кочевников. В случае регулярных перекочевок домохозяйств можно говорить об устойчивости традиционного скотоводства, тем самым и кочевого образа жизни.

Кочевки на длительное расстояние, частая смена пастбищ с короткими сроками пребываниями на одном месте, как правило, коррелируют 
с большим количеством поголовья скота в хозяйстве. Соответственно, целесообразность в постоянных перекочевках отсутствует в случае незначительного поголовья скота. Следует оговориться, что при неблагоприятных природно-климатических условиях возрастает интенсивность миграций и увеличивается их среднее расстояние.

Исходя из высказанного положения, сравнительное изучение схем кочевок представляется ключевой задачей в понимании не только имущественной дифференциации и социального положения кочевых домохозяйств, но и в оценке изменений кочевого образа жизни в целом.

В этом случае метод картографирования становится ведущим средством в деле получения необходимой информации. В настоящее время существуют разнообразные пакетные геоинформационные программы для обработки собранных данных и полноценного пространственного анализа. Они предоставляют широкий набор возможностей для графической обработки и визуализации информации.

Применение ГИС-технологий позволяет не только квантифицировать основные характеристики кочевого хозяйства, тем самым достигая определенного уровня верификации и объективизации исследований, но и увидеть скрытые взаимосвязи.

В оболочке ГИС можно объединить в единую многослойную карту разнородные источники (космоснимки, статистическую сводку, природные условия и т.д.). Это делает возможным проведение комплексного анализа.

Для исследователей доступны большое количество программного обеспечения для такого анализа. На сегодняшний день наиболее широко используются следующие системы: ArcGis, Maplnfo, Arclnfo, ArcView, QGIS, ArcEditor и др.

Подчеркнем, что они позволяют не только картографировать, но и обладают мощным набором инструментов для проведения анализа пространственных данных.

Первый этап состоит в накоплении и создании базы данных. В ходе полевых исследований методом опроса глав и членов кочевых домохозяйств формируется общее представление о характере перекочевок. Отмечается количество сезонных стоянок (как правило, это зимники, весенники, летники и осенники), сроки нахождения на каждом из них, заносятся данные по численности скота, видовому составу стада, а также сведения о фракторах, влияющих на пространственную организацию кочевых маршрутов. В первую очередь, это природно-географические условия: продуктивность пастбищ, ландшафт местности, водные ресурсы, солончаки и др. Во-вторых, это могут быть фракторы и иного рода: административные границы, ограничивающие расстояния кочевок, уровень плотности кочевых домохозяйств, наличие социальной инфраструктуры, близость к рынкам сбыта животноводческой продукции и т.д. 
Затем с помощью GPS-приемников фиксируются сезонные стоянки и, по возможности, записывается «трек» ежегодных кочевых маршрутов. Так, например, при проведении исследований в течение 2015-2018 гг. была сформирована база данных по отдельным территориям четырех крупных административных районов Монголии. Всего было проведено 28 глубинных интервью с главами домохозяйств сомонов (административная единица) Селенгинского аймака, в сомонах Центрального аймака - 35, в Булганском аймаке - 28 и в Хэнтэйском аймаке - 15. Были получены схемы кочевок более 100 домохозяйств.

Второй этап включает в себя непосредственную обработку полученных данных в ГИС-программах. Нами были использованы программные продукты геоинформационной обработки под общим названием ArcGIS, выпускаемые компанией ESRI. Она является мировым лидером в разработке программного обеспечения ГИС.

Базовые слои территорий получены из различных открытых интернет-ресурсов таких, как сервис Glovis Геологической службы США (USGS), ETOPO1, OpenStreetMap. Также были использованы космоснимки из картографических сервисов Google Earth Pro, Bing Maps. Они являются основой для географической привязки материалов по кочевкам. Имея данные по дистанционному зондированию можно создать геоинформационный слой, отображающий районы со скудной природной растительностью, деградированные пастбища, территории, подвергающиеся эрозии почвенного покрова вокруг водопоев и в местах перегона скота.

Атрибутивная база данных, содержащая данные различного характера, связана со слоями электронной карты. Поверх базовых слоев, отражающих рельеф местности, ее гидрографию, населенные пункты и инфраструктуру наносятся схемы кочевок с координатами сезонных стоянок.

Одним из важных средств геоинформационного анализа в линейке инструментов в программе ArcGIS является утилита Spatial Analyst Tools. B ней находится набор основных инструментов пространственного анализа [2].

В качестве примера, можно привести возможность проведения анализа плотности с помощью средств, расположенных в группе Density. Слой с нанесенными домохозяйствами в виде точечных объектов подвергается обработке, в результате которой мы получаем графическую информацию об удельной плотности. Кроме того, группировка объектов с использованием функции ядра показывает концентрацию кочевых хозяйств в тех или иных местах. Это может свидетельствовать об очагах напряженности и конфликтности в среде кочевников, поскольку скопление большого количества кочевых хозяйств сопровождается конкурентной борьбой за пастбища, источники воды и т.д.

Особое внимание привлекают набор средств по анализу расстояний между объектами исследований (Distance). Он включает в себя вычис- 
ления Евклидово расстояния (по прямой), расстояния со взвешенной стоимостью, путевого расстояния, маршрутов и коридоров между источниками с наименьшей стоимостью перемещения. В случае применения функции измерений Евклидово расстояния, то можно найти кратчайший прямой путь до интересующих объектов, например, родников, колодцев, населенных пунктов, школ и др. «Распределение по Евклидовому расстоянию» (Euclidean Allocation) определяет источники на основе максимальной близости. Инструмент «Стоимостное направление» (Cost Back Link) в качестве выходных данных предоставляет карту дорог, показывающую путь из любого объекта вдоль маршрута с наименьшей стоимостью перемещения до ближайшего источника. В условиях сложного рельефа плоскогорья, пересеченного отдельными возвышенностями, учет затрат на преодоления расстояний играет важную роль в перемещении кочевников.

Важным представляется также инструмент анализа солнечного излучения. В зимний период при низких температурах кочевники предпочитают располагаться на южных склонах холмов или гор, в местах где высокий уровень инсоляции. С помощью группы инструментов «Солнечное излучение» можно создать карту солнечного освещения по географической области для конкретных периодов времени. Анализ можно выполнить в двух направлениях. Инструмент «Область солнечного излучения» (Area Solar Radiation) используется для вычисления инсоляции по всему ландшафту. Для представления об уровне солнечного излучения конкретного местоположения понадобится инструмент «Точки солнечного излучения» (Points Solar radiation). Таким образом, можно создать прогнозную карту расселения скотоводов в зимний и осенний период.

Кроме того, можно создавать TIN-модели для визуализации ландшафрта в трехмерной плоскости в приложении ArcScene.

Подчеркнем также практическую пользу ГИС в сборе предварительной информации при подготовке и планировании полевых исследований, при выборе районов обследований.

Таким образом, применение ГИС-программ существенно расширяет возможности исследователей при изучении современного состояния кочевничества, выводя его на качественно новый уровень.

\section{Список использованной литературы и источников}

1. Коробов Д. С. Основы геоинформатики в археологии : учеб. пособие / Д. С. Коробов. - М. : МГУ им. М.В. Ломоносова, 2011. - 224 с.

2. ArcGIS Desktop [Электронный ресурс] - Режим доступа : http://desktop. arcgis.com/ru/arcmap/10.3/tools/spatial-analyst-toolbox/understanding-euclideandistance-analysis.htm

\section{Информация об авторе}

Гомбожапов Александр Дмитриевич - ведущий научный сотрудник отдела истории и культуры Центральной Азии, Институт монголоведения, буддо- 
логии и тибетологии СО РАН, 670047, г. Улан-Удэ, ул. Сахьяновой, 6; e-mail: agombozh@gmail.com.

\section{Author}

Alexander D. Gombozhapov — Leading Researcher of the Department of History and Culture of Central Asia, Institute of Mongolian, Buddhist and Tibetan Studies, Russian Academy of science, Siberian Branch, 6 Sakhyanova St., 670047, Ulan-Ude, Russia; e-mail: agombozh@gmail.com 